South African Journal for Research in Sport, Physical Education and Recreation, 2008, 30(1): 125-136. Suid-Afrikaanse Tydskrif vir Navorsing in Sport, Liggaamlike Opvoedkunde en Ontspanning, 2008, 30(1): 125-136. ISSN: 0379-9069

\title{
LEISURE MOTORHOMING: THE CASE OF THE MOTORHOME CLUB OF SOUTH AFRICA
}

\author{
$\mathrm{CH}$ (Neels) VAN HEERDEN \\ Department of Marketing and Communication Management, University of Pretoria, Pretoria, \\ Republic of South Africa
}

\begin{abstract}
This paper introduces caravanning and camping as a leisure activity that consists of a number of sequential experiences. The particular focus is on motorhoming as a form of caravanning/camping. The Motorhome Club of South Africa has a membership base of 670. A self-administered questionnaire surveyed the opinion of the entire membership base on certain aspects relating to the Motorhome Club and motorhoming in general. Two-hundred-and-ninety-nine questionnaires were returned. A Chi-square analysis identified a number of significant differences between specific demographic groups, most notably between age groups, and the number of club rallies attended. Only one significant difference was found between English and Afrikaans respondents - the latter are less inclined to visit historical sites (such as battlefield sites) than English respondents. The MCSA management committee needs to address the needs of two very important market segments, namely those younger than 60 years of age, and those who have not attended any MCSA Club rallies since 2003.
\end{abstract}

Key words: Leisure motorhoming; Motorhome Club of South Africa;

Club involvement; Tourism and travel experiences.

\section{INTRODUCTION}

It is estimated that there are approximately 700 camping facilities in South Africa. Most of these offer facilities, which cater specifically for the caravan and motorhome (a self-propelled motorised caravan) market. It is estimated that there are close to 107000 registered caravans in South Africa. The Motorhome Club of South Africa (MCSA) has a membership list of approx 670. No official figure is available on the total number of registered motorhomes in South Africa. The rental companies have close to 300 unites available.

Frequent camping excursions are very popular in the USA, Australia, the United Kingdom, most of Europe and South Africa. In these countries enthusiasts pack their tents, hitch their trailers or caravans, or start their motorhomes (a motorised caravan) to embark on an annual holiday, a short break (weekend), touring trip, to attend special events (festivals), or to go on a backpacking/hiking/sight-seeing trip.

A very narrow view regards camping merely as a type of tourist accommodation. This may create the impression that camping is the poor man's holiday option, and that everybody would rather stay in a five-star luxury hotel. On the contrary some people choose to enjoy the outdoors in a tent, caravan or motorhome. It is true that camping and caravanning can be a relatively economical holiday, but set-up costs are not negligible and investing in a caravan or 
motorhome can be hefty. A broader viewpoint is therefore that caravanning and camping is a leisure activity that includes a "series of experiences" therefore provides for wider analysis and offers entrepreneurial opportunities for providing differentiated destination options and innovative service offerings in terms of tours, routes and tourist package deals.

\section{Tourism and travel experiences}

Cooper et al. (1998), Ryan (1997) and Page et al. (2001) view tourism as a subset of leisure and that travel offers its own forms of recreation. Leisure is defined by Horner and Swarbrooke (2005: 22) as a "...series of experiences that people can undertake in their free time". They further add: "The management and marketing of leisure experiences has had a profound effect on the lives of people in history. Leisure is also big business and has spawned economic growth in countries".

Williams and Buswell (2003: 5) state that leisure can be viewed in terms of residual time, activity, function, state of mind or, (p.68) an additional dimension to a leisure and tourism product, namely a consumer experience. Another dimension to consider is Nash's conceptualisation of human use of leisure time, as cited in Torkildsen (1986: 464), where the tourist may inter alia be a creative participant (inventor), active participant (copying), and/or emotional participant (appreciative). Holiday experiences can also tie in to Maslow's hierarchy of needs, which range from affective (relaxing) to self-actualisation (exploration and/or being independent) (Ryan, 1997: 235). Because the customer is viewed as both consumer and co-producer (Norman, 1991: 234) and often plays an interactive role in shaping the experience; the leisure and tourism experience can be perceived as a service process that contains a series of sequential encounters. Williams and Buswell (2003: 72) add that: "By definition, tourism occurs over a longer time span than conventional leisure activities; although a holiday is made up of a series of discrete leisure activities, it is also evaluated by the tourist as an overall experience or as one package.

Manfredo et al. (1996) argue that recreational activities are behavioural pursuits that are instrumental in attaining psychological and physical goals. They argue that recreation emerges from a problem state - the need for participation in an activity (such as attending a club rally), while experience is the bundle of psychological outcomes desired. In other words the participant uses leisure time and money to participate in a chosen setting or context (such as being a member of a camping club) with certain outcomes in mind (such as socialising with other club members). Williams and Buswell (2003: 75-76) state that the experience can only be based on the interpretation or perceptions of the individual and that the way forward is to focus on identifying the psychological (or need-satisfactions) of leisure participation as perceived by the individual.

\section{Caravanning and camping}

Desk research has not uncovered any international scientific studies on motorhoming in general or the opinions or attitudes of members of a caravan/motorhome club in particular. Ingram (1996) identified camping as one area where research gaps exist. Recent desk research has uncovered very few scientific studies on caravanning, motorhoming or camping as a form of leisure tourism - so after 11 years the gaps still exist. Only three studies, which specifically focused on caravanning, could be found (one each in the UK, Australia and Germany), namely Southerton et al. (2001); Bell (2003); and Zanger et al. (2003). 
Participant observation on the caravanning industry by the researcher has lead to the following postulation: three major factors may influence satisfaction or dissatisfaction with the "total customer experience" at caravanning and camping tourism destinations. First of all, such destinations provide physical facilities (camping sites, ablutions, recreation etc.). Secondly, proximity or access to a natural, built or cultural environment (e.g. a game farm, mineral springs, the beach, a national park, Sun City or the KZN battlefields) is offered. Lastly, certain emotional and intrinsic value is created (e.g. the ability to relax and unwind at the destination and/or to explore the environment; belonging to a group such as a caravan, motorhome or camping club or a circle of family and friends; and/or participating in activities such as gameviewing, birding, tree-spotting, etc. at or close to a camp site). The interaction between the three aspects creates satisfaction or dissatisfaction with the total experience during a caravanning/camping/motorhoming trip. The overall satisfaction/dissatisfaction with such an excursion could for example have been influenced less by the physical facilities and/or the environment and more by certain intrinsic influences or vice versa.

Longer camping excursions (e.g. Summer holiday) are mostly organised independently with more of a focus on the location (seaside resort), with a greater tolerance for lower quality facilities or service quality standards. On the flipside of the coin a trend has emerged towards shorter-break excursions, particularly shorter school holidays at inland resorts and caravan or motorhome club rallies over weekends where the quality of the physical facilities may be more important than the environment.

The motorhoming life style is characterized by a strong desire to experience the outdoors and socialize with other campers while still retaining the comforts and conveniences of a familiar domicile (Green, 1978: 239). The uniqueness of motorhoming can be encapsulated by: motorhomers travel by personal vehicle, they supply their own accommodation, and they often bring most of their consumable supplies along. They are highly mobile and many would utilise the campsite as a base from where to explore the surrounding environment (game viewing, birding, tree-spotting etc.).

\section{Club involvement}

All of the aspects of a private club must be focused on a single objective - the enjoyment and satisfaction of members at a cost that is acceptable to them (York, 2002: 147). Cost could be related to club membership fees and the cost of participating in the club's activities. Enjoyment and satisfaction could be related to the non-financial gains when participating. As stated earlier people who caravan/motorhome like to enjoy "experiences" during their excursions.

Arnould and Price (1993) state that certain conditions exist that foster feelings of equality, linkage, belonging and group devotion to a goal. In my view members of the MCSA members may strive towards promoting the motorhoming lifestyle or to participate in the Club's activities or to utilise certain benefits offered by the Club. When examining the degree to which certain individuals participate in a Club's activities it is often found that certain members hardly ever participate while other are absolutely loyal and never miss an event or a rally. Sharpe (2005: 278) places this phenomenon in context: “...what we tend to find in leisure communities (such as the members of the MCSA) is a unification of the contradictory elements of intimacy and anonymity, obligation and freedom, and attachment. Attention to 
these unique characteristics can help us make sense of the experiences reported within these communities as well as better understand their role in fostering social solidarity."

MCSA Club members may therefore have different reasons for being intimately involved or just being a name on a list; certain members may feel that they have an obligation to participate, while others like to be very selective in when and how they participate. Deegan (1989: 16) stated that leisure rituals may be "meaningless for some, very important to others and only partly meaningful to most".

\section{MANAGEMENT PROBLEM}

In 2005 a new Management Committee for the Motorhome Club of South Africa was elected. It subsequently made a decision to manage its affairs according to business principles, including being more entrepreneurial, and to be more innovative in offering services to its membership base.

The new committee intends to reposition its scope of activities as they felt that a too small number of their members attended club rallies. They also wanted to measure the opinions of their members on certain matters relating to the MCSA and motorhoming in general. The eventual aim was to compile a new approach to recruitment of members and to change the Club's marketing focus.

The current mission of the MCSA state that camaraderie and social interaction is encouraged and that rallies and tour options are organised by the different regional committees. It is suspected that many members only belong to the MCSA because of the very economical vehicle insurance package offered.

A particular problem, which emerged while the researcher tried to find information on the industry, is the inability of the Department of Transport to provide information on the total number of registered motorhomes in South Africa. It is therefore not possible to determine the size and scope of the motorhome industry. If the MCSA's membership of 670 constitutes a large percentage of the total motorhome ownership figure then a growth strategy would be inappropriate. A relationship marketing and a customer service strategy should be planned where the current membership base is better served by for example offering a wider range of activities and services - especially to the under 60-segment. An example is an SMS service informing members of special offers at resorts, route planning and even financial incentives.

\section{PROBLEM STATEMENT}

Membership of a club such as the MCSA revolves around benefits gained through such membership. Being a member also incurs costs, such as membership fees and the costs of attending club rallies and functions. The management cadre of such a club has to ensure that benefits outweigh the costs of membership and that the changing needs of the members be satisfied. The problem is therefore that members should be frequently surveyed to determine their needs. If a large percentage of members are inactive the reasons for such inactiveness should also be determined and addressed. 


\section{OBJECTIVES OF THE STUDY}

The primary objective of this study was to measure the attitudes amongst MCSA members concerning the main benefits offered by the Club. Of particular importance was whether members' opinions on benefits concur with the mission and vision of the Club. Members were also surveyed on general motorhoming matters - such as whether they are positive about the future of motorhoming in South Africa. As a secondary objective membership needs in terms of organised rallies were analysed.

\section{METHODOLOGY}

The author of this paper was invited to attend a workshop of the MCSA management committee. At this workshop the Committee expressed the need to run the same questionnaire amongst their members. A list of questions was compiled that would lay the foundation of an exploratory study on the opinions and interests of members of the MCSA - on particular matters relating to motorhoming. The questionnaire was mailed to the 670 members of the Motorhome Club of South Africa. The aim of the questionnaire was to measure the preferences of MCSA members on different rally and/or tour options and to capture the attitudes and opinions of MCSA-members on the MCSA itself and on general motorhoming matters. Two-hundred-and-ninety-nine (44.6\%) completed questionnaires were returned.

\section{Exploratory statistics}

Tables 1 and 2 depict frequencies relating to the opinions of respondent members relating to MCSA and general motorhoming matters; and rally and tour options. Table 3 illustrates the biographical spread of respondents.

\section{TABLE 1: QUESTIONS RELATING TO MCSA \& GENERAL MOTORHOMING MATTERS}

\begin{tabular}{|l|l|l|l|l|l|}
\hline Attitude and opinion on: & & & & & \\
& & & & & \\
\hline MCSA rally schedules are convenient & 79 & 73 & 72 & 7 & 3 \\
\hline MCSA rallies are held at good quality resorts & 94 & 88 & 49 & 5 & 0 \\
\hline MCSA rally fees are affordable & 115 & 79 & 40 & 0 & 0 \\
\hline $\begin{array}{l}\text { Insurance is an important reason for MCSA } \\
\text { membership }\end{array}$ & 213 & 54 & 17 & 3 & 7 \\
\hline $\begin{array}{l}\text { Socialising is an important reason for MCSA } \\
\text { membership }\end{array}$ & 77 & 91 & 77 & 13 & 11 \\
\hline $\begin{array}{l}\text { Camaraderie is an important reason for MCSA } \\
\text { membership }\end{array}$ & 95 & 82 & 69 & 13 & 10 \\
\hline $\begin{array}{l}\text { I actively promote the MCSA among non- } \\
\text { MCSA members }\end{array}$ & 102 & 80 & 56 & 16 & 12 \\
\hline $\begin{array}{l}\text { Current MCSA activities satisfy all my } \\
\text { motorhoming needs }\end{array}$ & 64 & 82 & 78 & 17 & 10 \\
\hline
\end{tabular}




\begin{tabular}{|l|l|l|l|l|r|}
\hline $\begin{array}{l}\text { The Motorhomer magazine is a useful info } \\
\text { source }\end{array}$ & 185 & 85 & 18 & 5 & 1 \\
\hline www.caravanparks.com is a useful info source & 54 & 63 & 71 & 6 & 10 \\
\hline The MCSA web site is a useful info source & 43 & 58 & 81 & 7 & 8 \\
\hline $\begin{array}{l}\text { Caravan \& Outdoor Life magazine is a useful } \\
\text { info source }\end{array}$ & 103 & 97 & 46 & 14 & 10 \\
\hline $\begin{array}{l}\text { The star grading of resorts will raise resort } \\
\text { standards }\end{array}$ & 128 & 118 & 27 & 8 & 5 \\
\hline $\begin{array}{l}\text { A motorhome is more of a status symbol than a } \\
\text { caravan }\end{array}$ & 31 & 44 & 72 & 50 & 89 \\
\hline $\begin{array}{l}\text { Motorhoming is more convenient than } \\
\text { caravanning }\end{array}$ & 163 & 83 & 36 & 8 & 5 \\
\hline $\begin{array}{l}\text { Motorhoming in South Africa has a bright } \\
\text { future }\end{array}$ & 133 & 113 & 26 & 8 & 6 \\
\hline
\end{tabular}

\section{TABLE 2: QUESTIONS RELATING TO INTEREST IN CERTAIN RALLY/TOUR OPTIONS (FREQUENCY)}

\begin{tabular}{|c|c|c|c|c|c|}
\hline \multicolumn{6}{|c|}{$\begin{array}{l}\text { I am interested in the following rally and/or tour options (time, cost, and distance } \\
\text { permitting) }\end{array}$} \\
\hline Attitude and opinion on: & 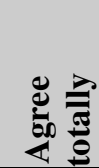 & 递 & 쥴 & 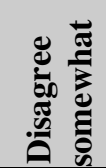 & 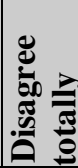 \\
\hline Festival tours (e.g. cherry festival) & 62 & 88 & 89 & 15 & 27 \\
\hline Activity sites (e.g. fly fishing) & 28 & 61 & 125 & 30 & 37 \\
\hline Bundu-bashing (e.g. of the beaten track) & 11 & 50 & 103 & 51 & 64 \\
\hline Cultural sites (e.g. cultural villages) & 11 & 54 & 127 & 47 & 40 \\
\hline $\begin{array}{l}\text { Historical sites (e.g. such as the Battlefield } \\
\text { routes) }\end{array}$ & 33 & 94 & 112 & 28 & 14 \\
\hline $\begin{array}{l}\text { Birding spots (e.g. Nylsvlei or St Lucia } \\
\text { Wetlands) }\end{array}$ & 71 & 100 & 87 & 14 & 13 \\
\hline $\begin{array}{l}\text { Game parks \& reserves (not only Kruger but } \\
\text { other parks as well) }\end{array}$ & 135 & 95 & 41 & 9 & 6 \\
\hline $\begin{array}{l}\text { Adventure (e.g. white water rafting, hiking, or } \\
\text { biking) }\end{array}$ & 27 & 57 & 114 & 30 & 50 \\
\hline
\end{tabular}




\section{TABLE 3: BIOGRAPHICAL INFORMATION (NUMBER OF RESPONDENTS INDICATED IN EACH CELL)}

\begin{tabular}{|c|c|c|c|c|c|c|c|c|c|c|c|c|c|}
\hline \multicolumn{14}{|c|}{ Biographical information (Frequency) } \\
\hline \multirow[t]{2}{*}{$\begin{array}{l}\text { Home } \\
\text { province? }\end{array}$} & $\mathrm{NC}$ & WC & \multicolumn{2}{|c|}{ EC } & \multicolumn{2}{|c|}{ KZN } & \multicolumn{2}{|c|}{ MPU } & \multicolumn{2}{|c|}{ FS } & LIMP & NW & $\begin{array}{l}\text { GA } \\
\text { UT }\end{array}$ \\
\hline & 1 & 81 & 24 & & 32 & & 11 & & 9 & & 6 & 11 & 117 \\
\hline \multicolumn{2}{|c|}{$\begin{array}{l}\text { How many years } \\
\text { have you been } \\
\text { motorhoming? }\end{array}$} & \multicolumn{2}{|c|}{ Less than 5} & \multicolumn{2}{|c|}{78} & \multicolumn{2}{|c|}{$5-10$} & \multicolumn{2}{|c|}{100} & $10+$ & 118 & & \\
\hline \multicolumn{2}{|c|}{$\begin{array}{l}\text { How old are } \\
\text { you? }\end{array}$} & \multicolumn{2}{|l|}{0 to 39} & \multicolumn{2}{|c|}{4} & \multicolumn{2}{|c|}{$40-49$} & \multicolumn{2}{|l|}{9} & $50-59$ & 60 & $60+$ & $\begin{array}{l}21 \\
9\end{array}$ \\
\hline \multicolumn{2}{|c|}{$\begin{array}{l}\text { Your home } \\
\text { language? }\end{array}$} & \multicolumn{2}{|c|}{ Afrikaans } & \multicolumn{2}{|c|}{118} & \multicolumn{2}{|c|}{ English } & \multicolumn{2}{|c|}{167} & Other & 11 & & \\
\hline \multicolumn{2}{|c|}{$\begin{array}{l}\text { How many } \\
\text { MCSA rallies } \\
\text { have you } \\
\text { attended since } \\
2003 \text { ? }\end{array}$} & \multicolumn{2}{|l|}{ None } & \multicolumn{2}{|c|}{155} & \multicolumn{2}{|c|}{$1-3$} & 29 & & $4-6$ & 20 & $60+$ & 92 \\
\hline
\end{tabular}

\section{Grouping of respondents}

Due to limitations created by the number of respondents in particular cells certain groups were formed, as illustrated in Table 4.

\section{TABLE 4: BIOGRAPHICAL INFORMATION (NUMBER OF RESPONDENTS INDICATED IN EACH CELL)}

\begin{tabular}{|c|c|}
\hline Groups & Descriptions \\
\hline a. Provinces & $\begin{array}{l}\text { - Coastal provinces (137 respondents) - (Western Cape, } \\
\text { KwaZulu-Natal, and Eastern Cape) } \\
\text { Inland provinces (155) (Gauteng, Mpumalanga, Free State, } \\
\text { Northwest, Limpopo and Northern Cape) }\end{array}$ \\
\hline $\begin{array}{l}\text { b. Years } \\
\text { motorhoming }\end{array}$ & $\begin{array}{l}\text { - } \quad \text { Less than } 5 \text { years (78 respondents); } \\
\text { - } \quad \text {-10 years (100 respondents), and } \\
\text { - } \quad 10+\text { years (118 respondents) }\end{array}$ \\
\hline c. Age & $\begin{array}{ll}\text { - } & 0-60(73 \text { respondents }) ; \text { and } \\
\text { - } & 60+(219)\end{array}$ \\
\hline d. Home language & $\begin{array}{ll}\text { - } & \text { Afrikaans (118); and } \\
\text { - } & \text { English (167) }\end{array}$ \\
\hline e. Rally attendance & $\begin{array}{ll}\text { - } & \text { No rallies attended (155); and } \\
\text { - } & \text { Rest of respondents (141) }\end{array}$ \\
\hline
\end{tabular}

\section{Chi-square tests}

Two Chi-square tests were conducted:

a) Test for significant differences (each of a. to e. in Table 4 with each of statements in Table $1)$. 
b) Test for significant differences (each of a. to e. in Table 4 with each of statements in Table 2).

Only those respondent groupings that indicated statistically significant differences in relation to certain questions will be reported in the next section.

\section{FINDINGS}

\section{Tests for statistical significance}

Tables 5 to 8 depict categories that were statistically significant within a 95\% level of confidence (...that means that we can be $95 \%$ confident that the response would be representative for all members of the MCSA, whether they responded or not - i.e. whether they completed a questionnaire or not).

\section{TABLE 5: INVOLVEMENT WITH MCSA ACTIVITIES (STATISTICALLY SIGNIFICANT WITHIN A 95\% LEVEL OF CONFIDENCE (CHI- SQUARE TEST))}

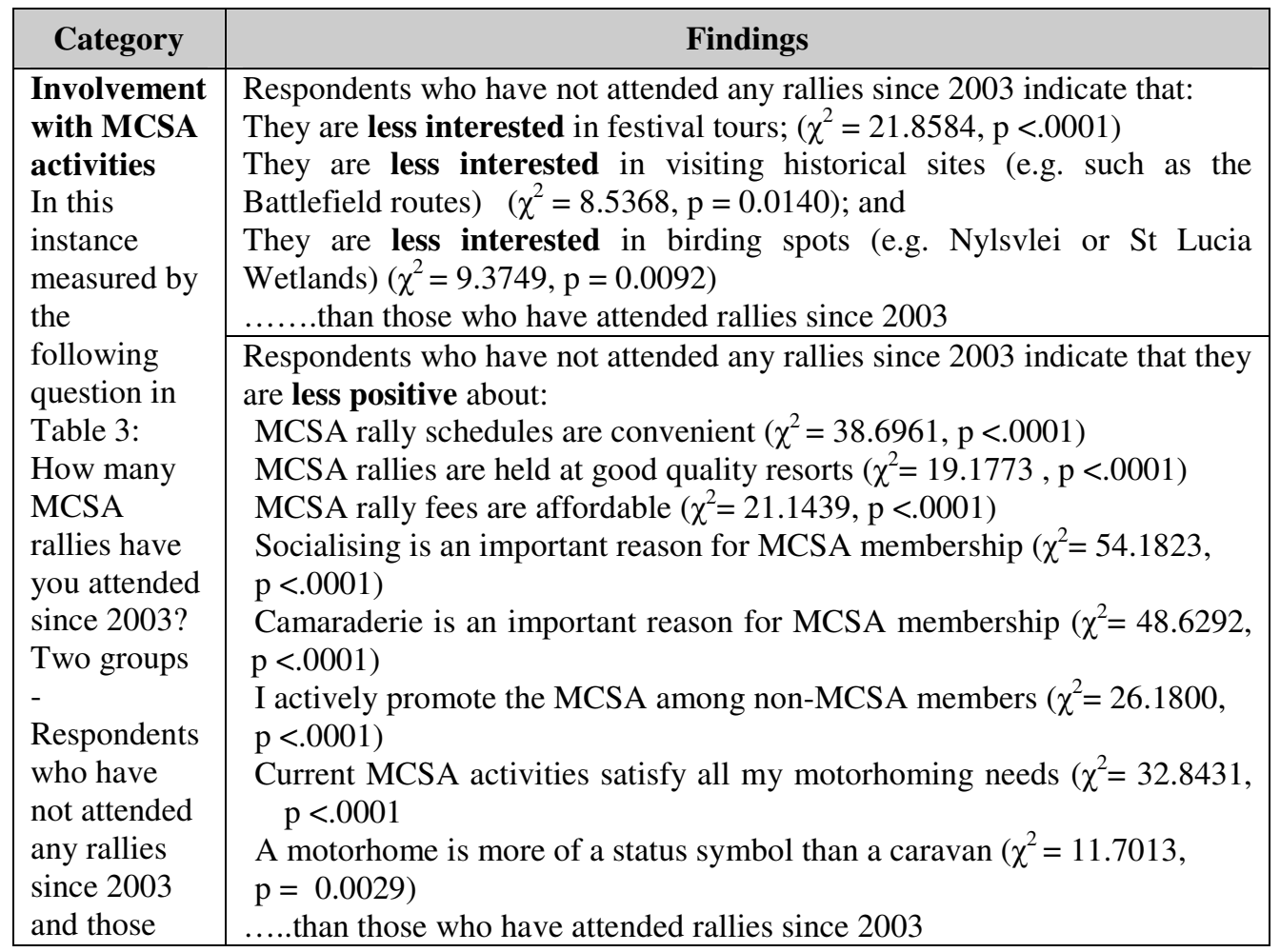




\begin{tabular}{|l|l|}
\hline $\begin{array}{l}\text { that have } \\
\text { attended } \\
\text { rallies since } \\
2003\end{array}$ & $\begin{array}{l}\text { Respondents who have not attended any rallies since 2003 indicate that they } \\
\text { are more positive about: } \\
\text { Insurance is an important reason for MCSA membership }\left(\chi^{2}=10.9940,\right. \\
\mathrm{p}=0.0041) \\
\text { www.caravanparks.com is a useful info source }\left(\chi^{2}=7.1902, \mathrm{p}=0.0275\right) \\
\text { Caravan \& Outdoor Life magazine is a useful info source }\left(\chi^{2}=13.2583,\right. \\
\mathrm{p}=0.0013) \\
\text {......than those who have attended rallies since 2003 }\end{array}$ \\
\hline
\end{tabular}

$\chi^{2}=$ Chi-square coefficient for $\mathrm{p} \leq 0.05$

\section{TABLE 6: AGE (STATISTICALLY SIGNIFICANT WITHIN A 95\% LEVEL OF CONFIDENCE (CHI-SQUARE TEST))}

\begin{tabular}{|c|c|}
\hline Category & Findings \\
\hline \multirow{2}{*}{$\begin{array}{l}\text { Measured } \\
\text { over two } \\
\text { groups: } \\
\text { Those } \\
\text { younger } \\
\text { than } 60 \text { and } \\
\text { those older } \\
\text { than } 60\end{array}$} & $\begin{array}{l}\text { Respondents younger than } 60 \text { are more positive about: } \\
\text { Bundu-bashing (e.g. of the beaten track) }\left(\chi^{2}=8.3222, p=0.0156\right) \\
\text { Adventure (e.g. white water rafting, hiking, or biking) }\left(\chi^{2}=16.5957,\right. \\
p=0.0002) \\
\text { www.caravanparks.com is a useful info source }\left(\chi^{2}=8.4113, p=0.0149\right) \\
\text { The MCSA web site is a useful info source }\left(\chi^{2}=7.7832, p=0.0204\right)\end{array}$ \\
\hline & $\begin{array}{l}\text { Respondents younger than } 60 \text { are less positive about: } \\
\text { Camaraderie is an important reason for MCSA membership }\left(\chi^{2}=5.9694, \mathrm{p}=\right. \\
\left.0.0506^{* *}\right) \\
\text { I actively promote the MCSA among non-MCSA members }\left(\chi^{2}=8.5189, \mathrm{p}=\right. \\
0.0141)\end{array}$ \\
\hline
\end{tabular}

$\chi^{2}=$ Chi-square coefficient for $\mathrm{p} \leq 0.05$

** Borderline outside a $95 \%$ level of confidence)

\section{TABLE 7: LANGUAGE (STATISTICALLY SIGNIFICANT WITHIN A 95\% LEVEL} OF CONFIDENCE (CHI-SQUARE TEST))

\begin{tabular}{|c|c|}
\hline Category & Findings \\
\hline $\begin{array}{l}\text { Measured for the two language } \\
\text { groups }\end{array}$ & $\begin{array}{l}\text { Afrikaans-speaking respondents are less interested in } \\
\text { visiting historical sites (e.g. such as the Battlefield } \\
\text { routes) than English-speaking respondents. }\left(\chi^{2}=\right. \\
7.4537, \mathrm{p}=0.0241) \\
\text { No statistical difference between Afrikaans and } \\
\text { English speaking respondents on any other statement } \\
\text { (which is a significant finding in itself). }\end{array}$ \\
\hline
\end{tabular}




\section{TABLE 8: HOW LONG HAVE YOU BEEN MOTORHOMING? (STATISTICALLY SIGNIFICANT WITHIN A 95\% LEVEL OF CONFIDENCE (CHI- SQUARE TEST))}

\begin{tabular}{|c|l|}
\hline \multicolumn{1}{|c|}{ Category } & \multicolumn{1}{c|}{ Findings } \\
\hline \multirow{5}{*}{$\begin{array}{c}\text { How long have you been } \\
\text { motorhoming }\end{array}$} & $\begin{array}{l}\text { Respondents who have been motorhoming for more } \\
\text { than 10 years are less positive about rally tours to: } \\
\text { Game parks \& reserves (not only Kruger but other } \\
\text { parks as well) than those who have been } \\
\text { motorhoming for between 5 and 10 years. } \\
\left(\chi^{2}=9.5348, \mathrm{p}=0.0490\right)\end{array}$ \\
\cline { 2 - 2 } & $\begin{array}{l}\text { Respondents who have been motorhoming for more } \\
\text { than 10 years are more neutral about the statement: } \\
\text { Camaraderie is an important reason for MCSA } \\
\text { membership, than the other two groups. } \\
\left(\chi^{2}=12.3646, \mathrm{p}=0.0148\right.\end{array}$ \\
\hline
\end{tabular}

$\chi^{2}=$ Chi-square coefficient for $\mathrm{p} \leq 0.05$

\section{Tests for practical significance}

Ellis and Steyn (2003: 51) state that statistical significance (eg. when the p-value is smaller than 0.05 as illustrated in Tables 5 to 8 ) does not necessarily imply that the result is important in practice. Although some Chi-square tests in this study indicated statistical significance, further analysis is required to test whether the relationships are large enough to be important. The effect size for a $2 \times 2$ contingency table is given by:

$\mathrm{w}=\sqrt{\chi 2 / \mathrm{n} .} \quad$ A relationship with $\mathrm{w}>0.5$ is considered as practically significant.

A series of calculations, on relationships depicted in Tables 5 to 8 , uncovered only three that were practically significant (shown in Table 9).

\section{TABLE 9: PRACTICAL SIGNIFICANCE OF RELATIONSHIPS $(\mathbf{W} \geq \mathbf{0 . 5})$}

\begin{tabular}{|l|l|}
\hline \multicolumn{1}{|c|}{ Category } & \multicolumn{1}{c|}{ Findings } \\
\hline & $\begin{array}{l}\text { Respondents who have not attended any rallies since } \\
\text { 2003 are less in agreement that: "MCSA rally } \\
\text { schedules are convenient" }\end{array}$ \\
\cline { 2 - 2 } $\begin{array}{l}\text { Two groups - Respondents who } \\
\text { have not attended any rallies since } \\
2003 \text { and those that have attended } \\
\text { rallies since } 2003\end{array}$ & $\begin{array}{l}\text { Respondents who have not attended any rallies since } \\
2003 \text { are less in agreement that: "Socialising is an } \\
\text { important reason for MCSA membership" }\end{array}$ \\
\cline { 2 - 2 } & $\begin{array}{l}\text { Respondents who have not attended any rallies since } \\
2003 \text { are less in agreement that: "Camaraderie is an } \\
\text { important reason for MCSA membership" }\end{array}$ \\
\hline
\end{tabular}

It can be deduced that there are important practical differences between respondents who have attended rallies since 2003 and those who haven't in terms of three variables - convenience of 
scheduled rallies, socialising as an important reason for MCSA membership, and camaraderie is an important reason for MCSA membership.

\section{MANAGERIAL IMPLICATIONS AND CONCLUSION}

Caravanning and camping is a leisure activity that includes a "series of experiences" which therefore provides for wider analysis and offers entrepreneurial opportunities for providing differentiated destination options and innovative service offerings in terms of tours, routes and tourist package deals. The responses indicate that specific actions are needed to change perceptions or to provide different incentives to increase involvement of those who have not attended any rallies since 2003. It is not yet conclusive whether the MCSA is offering the right "blend of experiences".

Insurance is probably one of the most important factors for MCSA membership amongst most of the inactive members. Members younger that 60 (who can be regarded as the "future" of the MCSA) and inactive members are not that positive about the current selling proposition of the MCSA (socialising and camaraderie). A different selling proposition should be developed to address their particular needs. The MCSA should use www.caravanparks.com and Caravan \& Outdoor Life Magazine as sources to communicate with MCSA-members younger than 60 to gain a higher visibility and to inform them about the advantages offered by the MCSA. The finding that respondents younger than 60 are less positive about: "I actively promote the MCSA among non-MCSA members" is a concern.

It is strongly recommended that the MCSA consult with counterparts in other countries, especially the UK and Australia. In the UK their Caravan Club, with a membership of 900 000 , offers a wide range of tangible benefits to its members. Their focus is less on organising rallies but more on promoting the lifestyle and offering financial benefits. The UKCC even owns its own resorts for the exclusive use of its members. The MCSA should investigate more innovative benefits in terms of financial rewards.

Table 5 provides an indication of aspects that respondents who have not attended any rallies since 2003 are feeling less positive about. The MCSA membership committee should address these. Finally, the MCSA should address the needs of two very important segments - those younger than 60 and those who have not attended any rallies since 2003. These segments might just create a more prosperous future to the MCSA.

The tests for practical significance highlighted that statistically significant results should, at face value, not always be regarded as important. The MCSA management committee should take note of the results depicted in Table 9. "Socializing" and "camaraderie", as marketing slogans, are not viewed with much enthusiasm by a significant segment of the MCSA membership base. Perhaps more tangible membership benefits should be emphasized. The most important finding in this study is that many members regard the MCSA rally schedule as "inconvenient". Members' needs concerning scheduling, destinations and timing should be explored further. 


\section{REFERENCES}

ARNOULD, E.J. \& PRICE, L.L. (1993). River magic: Extraordinary experience and the extended service encounter. Journal of Consumer Research, 20: 24-45.

BELL, B. (2003). Toward a better understanding of the Australian 'caravanning' experience. Paper presented at the 13th International Conference of CAUTHE -' Riding the Wave of Tourism and Hospitality Research'. Coffs Harbour, Australia; 5-8 February.

COOPER, C.; FLETCHER, J.; GILBERT, D.; SHEPHERD, E.D. \& WANHILL, S. (1998). Tourism principles and practice ( $2^{\text {nd }}$ ed.). London: Prentice Hall.

DEEGAN, M.J. (1989). American ritual dramas: social rules and cultural meanings. New York, NY: Greenwood Press.

ELLIS, S.M. \& STEYN, H.S. (2003). Practical significance (effect sizes) versus or in combination with statistical significance (p-values). Management Dynamics. 12(4): 51-53.

GREEN, F.B. (1978). Recreation vehicles - a perspective. Annals of Tourism Research, October/December: 429-439.

HORNER, S.E. \& SWARBROOKE, J. (2005). Leisure marketing - a global perspective. Amsterdam: Elsevier, Butterworth-Heinemann.

INGRAM, H. (1996). Clusters and gaps in hospitality and tourism academic research. International Journal of Contemporary Hospitality Management. 8/7: 91-95.

MANFREDO, M.J.; DRIVER, B.L. \& TARRANT M.A. (1996). Measuring leisure motivation: a metaanalysis of the recreation experience preference scales. Journal of Leisure Research, 3: 188-213.

NORMAN, R. (1991). Service Management. Chichester: John Wiley \& Sons.

PAGE, S.J.; BRUNT, P.; BUSBY, G. \& CONNELL, J. (2001). Tourism: a modern synthesis. London: Thomson Learning.

RYAN, C. (1997). From motivation to assessment. In C. Ryan (Ed.). The tourist experience. London: Cassel.

SHARPE, E.K. (2005). Delivering communitas: wilderness adventure and the making of community. Journal of Leisure Research, 37(3): 255-280, third quarter.

SOUTHERTON, S.; SHOVE, E.; WARDE, A. \& DEEM, R. (2001). The social worlds of caravaning: objects, scripts and practices. Sociological Research Online, 6(2) [http://www.socresonline.org.uk/6/2/southerton.html].

TORKILDSEN, G. (1986). Leisure and Recreation Management ( $2^{\text {nd }}$ ed.). London: E. and F. Spon.

WILLIAMS, C. \& BUSWELL, J. (2003). Service quality in tourism. Wallingford (Oxfordshire, UK): CABI Publishing.

YORK, B. (2002). Private club trends in the USA - a statistical review. International Journal of Contemporary Hospitality Management. 14(3): 147-151.

ZANGER, C.; KAMINSKI, S. \& WENISCH, M. (2003). Der Deutsche Caravaning-Markt-Nachfragerverhalten, Segmentierungsansätze und. Praktische Marketimplikationen. Tour; 1(5): 7.

Prof. C.H. (Neels) van Heerden: Department of Marketing and Communication Management, University of Pretoria, Pretoria 0002, Republic of South Africa. Tel.: +27 (0)12 420 3145, E-mail: nheerden@ hakuna.up.ac.za 